\title{
OBSERVATIONS CONCERNING THE CHOLATE: CHOLESTEROL RELATIONSHIP IN CLINICAL AND EXPERIMENTAL NEPHROSIS 1, 2
}

\author{
BY RAY H. ROSENMAN, MEYER FRIEDMAN, AND SANFORD O. BYERS
}

(From the Mount Zion Hospital, Harold Brunn Institute, San Francisco, Calif.)

(Submitted for publication August 13, 1952; accepted November 14, 1952)

The occurrence of hypercholesteremia in the nephrotic state is a long recognized phenomenon (1), but its mechanism remains to be determined. Apparently the hypercholesteremia cannot be ascribed to a primary "lipoid degeneration" of the kidney (2).

Recently, studies from this laboratory (3-6) have indicated that there is a marked derangement of cholate metabolism in certain clinical and experimental states of hypercholesteremia. It therefore was considered of interest to investigate the metabolism of this particular steroid in both clinical and experimental nephrosis.

\section{The Cholate: Cholesterol Relationship in Clini- cal Nephrosis}

\section{(1) Methods}

Samples of blood serum were obtained from $18 \mathrm{pa}-$ tients suffering from nephrosis for periods of time varying from one to 24 months. There were 12 males and 6 females, varying in age from 3 to 65 years. "Lipoid" nephrosis was believed present in 11 instances, the nephrotic stage of chronic glomerulonephritis in six patients, and Kimmelstiel-Wilson syndrome with nephrosis in one case. Serum cholesterol and cholate concentrations were determined in each instance, according to technics previously described ${ }^{3}(7,8)$.

\section{(2) Results}

The cholate content of the serum invariably was elevated if the patients also were hypercholesteremic (see Table I). Thus, the serum cholesterol concentrations of 15 nephrotic patients with hypercholesteremia varied from 450 to $1060 \mathrm{mg}$. per

1 Aided by grants from the American Heart Association, Monterey, California, Heart Association, and the United States Public Health Service.

2 Presented in part at the May, 1952, meeting of the American Society for Clinical Investigation, Atlantic City, N. J.

${ }^{3}$ A small percentage of the result obtained by this technic may represent noncholate chromogen substances.
$100 \mathrm{cc}$, and their serum cholates from 10.0 to $44.0 \mathrm{mg}$. per $100 \mathrm{cc}$. These values were in marked contrast to those obtained from 25 normal human subjects in whom the serum cholesterol ranged from 110 to $280 \mathrm{mg}$. per $100 \mathrm{cc}$., and the serum cholate from 1.7 to $7.2 \mathrm{mg}$. per $100 \mathrm{cc}$.

On the other hand, the serum cholate concentrations were found to be normal $(1.0,6.4,5.0 \mathrm{mg}$. per $100 \mathrm{cc}$.) in three nephrotic patients with normal serum cholesterol levels $(110,250,200 \mathrm{mg}$. per 100 cc., respectively). This finding of "hypercholatemia" in nephrotic patients only when they also exhibited hypercholesteremia prompted the following experimental investigations:

\section{The Cholate: Cholesterol Relationship in Ex- perimental Nephrosis}

\section{A. The plasma cholesterol and cholate concen- trations in rats with experimental nephrosis}

The studies of Heymann and Lund (9) have shown that the chronic disease produced in rats by the injection of rabbit anti-rat kidney serum closely simulates the nephrotic state as it is observed in human subjects. This method, therefore,

TABLE I

The average serum cholesterol and cholate concentration in nephrotic patients

\begin{tabular}{|c|c|c|c|}
\hline Type of patient & $\begin{array}{l}\text { No. of } \\
\text { patients }\end{array}$ & $\begin{array}{c}\text { Average } \\
\text { plasma } \\
\text { cholesterol } \\
(m g . / 100 c c .)\end{array}$ & $\begin{array}{c}\text { Average } \\
\text { plasma } \\
\text { cholate } \\
\text { (mg./100 cc.) }\end{array}$ \\
\hline $\begin{array}{l}\text { Normal control } \\
\text { Range: } \\
\text { S.E. Mean: }\end{array}$ & 25 & $\begin{array}{c}228 \\
(110-280) \\
\quad \pm 8.7\end{array}$ & $\begin{array}{c}5.3 \\
(1.7-7.2) \\
\pm 0.26\end{array}$ \\
\hline $\begin{array}{l}\text { Nephrotic } \\
\text { (hypercholesteremic) } \\
\text { Range: } \\
\text { S.E. Mean: }\end{array}$ & 15 & $\begin{array}{c}695 \\
(450-1060) \\
\pm 45.0\end{array}$ & $\begin{array}{c}19.2 \\
(10.0-44.0) \\
\pm 2.8\end{array}$ \\
\hline $\begin{array}{l}\text { Nephrotic } \\
\text { (normocholesteremic) } \\
\text { Range: }\end{array}$ & ) & $\begin{array}{c}180 \\
(110-250)\end{array}$ & $\begin{array}{c}4.4 \\
(1.0-6.4)\end{array}$ \\
\hline
\end{tabular}


was utilized to study cholate metabolism in experimental nephrosis.

\section{(1) Methods}

Rabbit anti-rat kidney serum, prepared and sent to us by $\mathrm{Dr}$. A. I. Knowlton (10), was injected intravenously into immature (4 to 8 weeks old) male rats (Long-Evans strain). One-third cubic centimeter of this serum was injected into each of 30 rats on each of two successive days. Renal disease, as indicated by the onset of marked albuminuria and hyperlipemia (9), developed within one week in all but two rats.

Plasma cholesterol and cholate concentrations were determined in 22 rats prior to, and one week following, the injections of anti-rat kidney serum. Similar analyses were obtained in a group of 10 normal control animals.

\section{(2) Results}

Both hypercholesteremia and hypercholatemia consistently were found (see Table II). The average plasma cholesterol of the 22 nephrotic rats rose from $71 \mathrm{mg}$. per $100 \mathrm{cc}$. (prior to the injection of immune serum) to $460 \mathrm{mg}$. per $100 \mathrm{cc}$., one week after the injections of anti-rat kidney serum. The average plasma cholate concentration of the same rats rose from 5.9 to $23.1 \mathrm{mg}$. per $100 \mathrm{cc}$.

\section{B. The rate of disappearance of cholate from the blood of nephrotic rats following its in- travenous injection}

\section{(1) Methods}

In order to test the ability of the nephrotic rats to eliminate cholate from their blood, the following experiment was performed. Twenty-five milligrams of sodium cholate were injected intravenously into 11 of the above . nephrotic rats and into 10 control animals. Nephrotic rats were selected whose plasma cholate levels were only moderately elevated at the time of the injection. In each instance samples of blood plasma were obtained at four different times; prior to, and immediately and one and two hours after the injection of sodium cholate.

\section{(2) Results}

The intravenous injection of cholate induced a considerable and comparable rise of plasma cholate in both the nephrotic and the control animals (see Table III). The excess cholate largely disappeared from the plasma of the control group of rats within one hour after its administration. It was eliminated entirely at the end of two hours. However, considerable elevation of plasma cholate was found in the nephrotic rats at the end of one hour and this persisted even two hours after the cholate injection. Thus, there appeared to be a delay in the disappearance of the injected cholate from the plasma of the nephrotic rats.

\section{The effect of cholate administration upon the plasma cholesterol of nephrotic rats}

\section{(1) Methods}

Heymann and Lund (9) observed that the initial hypercholesteremia which developed in nephrotic rats soon decreased to somewhat lower although still elevated levels. This finding prompted the following experiment: One hundred milligrams of cholate were fed daily by gastric intubation to 11 of 17 nephrotic rats (one week after the injection of immune serum). The same amount of cholate was given to 11 of 19 control animals. The plasma cholesterol was determined in each instance prior to the feeding of cholate and again five days later. Similar determinations were obtained in the remaining nephrotic and control rats that did not receive cholate feedings. All rats were fed the stock laboratory ration.

\section{(2) Results}

The elevated plasma cholesterol levels of the 11 nephrotic rats to which cholate was fed, were maintained; their average plasma cholesterol rose from $495 \mathrm{mg}$. per $100 \mathrm{cc}$. to $508 \mathrm{mg}$. per $100 \mathrm{cc}$. (see Table IV). On the other hand, the average plasma cholesterol of the six nephrotic rats not receiving

TABLE II

Average plasma cholesterol and cholate concentration of nephrotic rats

\begin{tabular}{|c|c|c|c|c|c|c|}
\hline \multirow[b]{3}{*}{ Type of rat } & \multirow{3}{*}{$\begin{array}{c}\text { No. of } \\
\text { rats }\end{array}$} & \multirow{3}{*}{$\begin{array}{c}\text { Average } \\
\text { weight } \\
\text { gm. }\end{array}$} & \multicolumn{4}{|c|}{ Average plasma concentration (mg./100 cc.) } \\
\hline & & & \multicolumn{2}{|c|}{$\begin{array}{l}\text { Before injection of } \\
\text { immune serum }\end{array}$} & \multicolumn{2}{|c|}{$\begin{array}{c}\text { After injection of immune } \\
\text { serum (1 week) }\end{array}$} \\
\hline & & & Cholesterol & Cholate & Cholesterol & Cholate \\
\hline $\begin{array}{l}\text { Nephrotic } \\
\text { Range: }\end{array}$ & 22 & 126 & $\begin{array}{c}71 \\
(63-81)\end{array}$ & $\begin{array}{c}5.9 \\
(3.1-7.7)\end{array}$ & $\begin{array}{c}460 \\
(190-800)\end{array}$ & $\begin{array}{c}23.1 \\
(8.2-42.0)\end{array}$ \\
\hline $\begin{array}{l}\text { Control } \\
\text { Range: }\end{array}$ & 10 & 163 & $\begin{array}{c}73 \\
(63-89)\end{array}$ & $\begin{array}{c}6.8 \\
(5.1-9.2)\end{array}$ & $\begin{array}{c}58.2 \\
(42.0-75.0)\end{array}$ & $\begin{array}{c}5.3 \\
(1.5-10.5\end{array}$ \\
\hline
\end{tabular}


TABLE III

Rate of disappearance of injected cholate from plasma of nephrotic rats

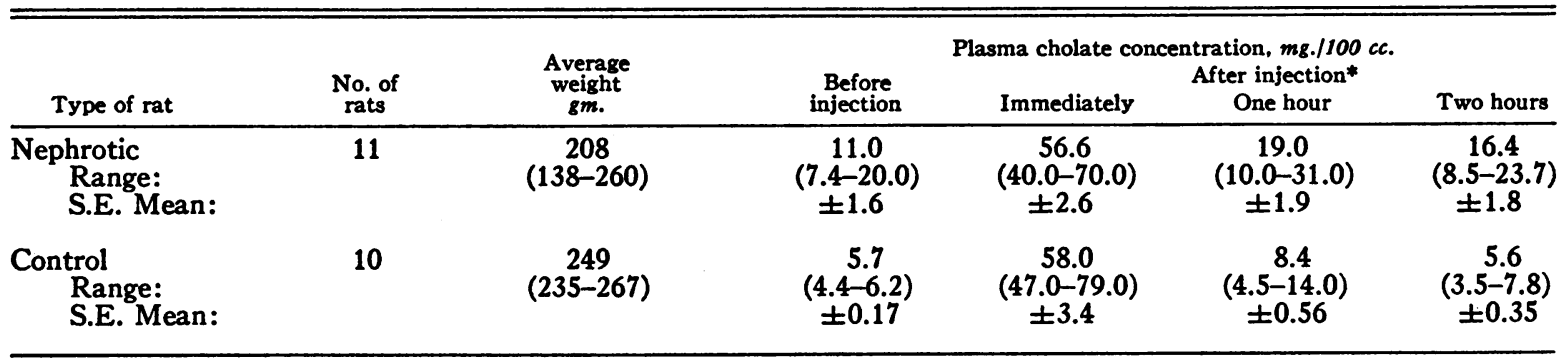

* $25 \mathrm{mg}$. sodium cholate injected intravenously.

cholate feedings fell from $417 \mathrm{mg}$. per $100 \mathrm{cc}$. to $211 \mathrm{mg}$. per $100 \mathrm{cc}$. The cholate feedings also induced an elevation of plasma cholesterol in the normal animals, their average concentration rising from $73 \mathrm{mg}$. per $100 \mathrm{cc}$. to $99 \mathrm{mg}$. per $100 \mathrm{cc}$.

\section{DISCUSSION}

The studies described above have shown that an excess of cholate is present in the blood plasma of nephrotic human subjects, as well as in the plasma of rats with experimentally induced nephrosis, whenever hypercholesteremia also is present. This excess of cholate may well be responsible for the reduced surface tension of nephrotic blood, a phenomenon first described by Clausen (11) and later confirmed by Leiter (12).

TABLE IV

Effect of cholate administration upon plasma cholesterol of nephrotic rats

\begin{tabular}{|c|c|c|c|c|}
\hline \multirow[b]{2}{*}{ Type of rat } & \multirow[t]{2}{*}{$\begin{array}{l}\text { No. } \\
\text { of } \\
\text { rats }\end{array}$} & \multirow{2}{*}{$\begin{array}{c}\text { Aver- } \\
\text { age } \\
\text { weight } \\
\text { gm. }\end{array}$} & \multicolumn{2}{|c|}{$\begin{array}{c}\text { Plasma cholesterol } \\
\text { mg. } / 100 \mathrm{cc}\end{array}$} \\
\hline & & & Beginning & After 5 days \\
\hline $\begin{array}{l}\text { I. Normal } \\
\text { A. Without cholate } \\
\text { Range: } \\
\text { S.E. Mean: } \\
\text { B. With cholate* } \\
\text { Range: } \\
\text { S.E. Mean: }\end{array}$ & 11 & 110 & $\begin{array}{c}68 \\
(54-72) \\
\pm 1.94 \\
73 \\
(57-92) \\
\pm 1.98\end{array}$ & $\begin{array}{c}64 \\
(50-70) \\
\pm 2.25 \\
99 \\
(61-142) \\
\pm 8.83\end{array}$ \\
\hline $\begin{array}{l}\text { II. Nephrotic } \\
\text { A. Without cholate } \\
\text { Range: } \\
\text { S.E. Mean: } \\
\text { B. With cholate* } \\
\text { Range: } \\
\text { S.E. Mean: }\end{array}$ & 11 & 140 & $\begin{array}{c}417 \\
(234-800) \\
\pm 80.5 \\
495 \\
(266-678) \\
\pm 40.10\end{array}$ & $\begin{array}{c}211 \\
(146-260) \\
\pm 16.6 \\
508 \\
(214-661) \\
\pm 68.90\end{array}$ \\
\hline
\end{tabular}

* $100 \mathrm{mg}$. sodium cholate fed daily.
Other studies from this laboratory (4) have shown that hypercholatemia is almost invariably present in various clinical states of hypercholesteremia. This fact in itself might be only of incidental interest were it not for the observation (3) that when hypercholatemia is induced experimentally in the rat, a state of hypercholesteremia immediately develops. In view of these findings, the possible relationship between the excess cholate and cholesterol in the blood of the nephrotic animal may have considerable importance. This is discussed more extensively in a forthcoming study (13).

\section{SUMMARY}

An excess accumulation of bile acid (hypercholatemia) was found in the blood of human subjects with nephrosis and in the blood of rats in which experimental nephrosis had been induced by injection of anti-rat kidney serum, whenever hypercholesteremia also was present. The nephrotic rat also was found to exhibit a diminished ability to rid his blood of excess injected cholate. Finally, the feeding of cholate to nephrotic rats appeared to prevent the decrease of plasma cholesterol, which usually occurred, following its initial maximal rise.

\section{REFERENCES}

1. Bloor, W. R., The blood lipoids in nephritis. J. Biol. Chem., 1917, 31, 575.

2a. Lowenthal, K., Zur Frage der Lipoidnephrose. Virchows Arch. f. path. Anat., 1926, 261, 109.

2b. Epstein, A. A., Ueber Diabetes albuminuricus die sogenannte chronische Nephrose. Arch. Verdauungskrankheiten, 1928, 44, 31.

3. Friedman, M., and Byers, S. O., Cholic acid: an ade- 
quate stimulus for hypercholesteremia in the normal fasting rat. Proc. Soc. Exper. Biol. \& Med., 1951, 78, 528.

4. Friedman, M., Byers, S. O., and Rosenman, R. H., The accumulation of serum cholate and its relationship to hypercholesteremia. Science, 1952, 115, 313.

5. Byers, S. O., and Friedman, M., Effect of various bile acids on the hypercholesteremia following biliary obstruction in the rat. Am. J. Physiol., 1952, $168,138$.

6. Friedman, M., and Byers, S. O., Production and excretion of cholesterol in mammals. VI. Bile acid accumulation in production of hypercholesteremia occurring after biliary obstruction. Am. J. Physiol., 1952, 168, 292.

7. Byers, S. O., Friedman, M., and Michaelis, F., Observations concerning the production and excretion of cholesterol in mammals. I. Plasma cholesterol after bile duct ligation and free cholesterol injection. J. Biol. Chem., 1950, 184, 71.

8. Friedman, M., Byers, S. O., and Michaelis, F., Bile acid content of rat bile and of normal and icteric rat plasma. Am. J. Physiol., 1951, 164, 786.

9. Heymann, W., and Lund, H. Z., Nephrotic syndrome in rats. Pediatrics, 1951, 7, 691.

10. Knowlton, A. I., Stoerk, H., Seegal, B. C., and Loeb, E. N., Influence of adrenal cortical steroids upon the blood pressure and the rate of progression of experimental nephritis in rats. Endocrinology, 1946, 38, 315.

11. Clausen, S. W., Parenchymatous nephritis. III. The surface tension of the blood serum. Am. J. Dis. Child., 1925, 29, 594.

12. Leiter, L., Nephrosis. Medicine, 1931, 10, 135.

13. Byers, S. O., Friedman, M., and Rosenman, R. H., Review: On the regulation of blood cholesterol. Metabolism. 1: 479, 1952. 